in a political sense, immoral as well as practically mischievous. Already terrible evils have followed. The independent tribes, on our side of the limit, believe that in I893 we annexed their hills, and only now refrain from a military occupation because of the martial prowess of the clansmen. All the frontier wars and the exacerbation of fanaticism all along the line since I 893 are traceable directly or indirectly to this unlucky treaty. Implacable suspicion and armed watchfulness on the part of the highlanders, as well as those violent outbreaks which have cost us so dearly, are part of the

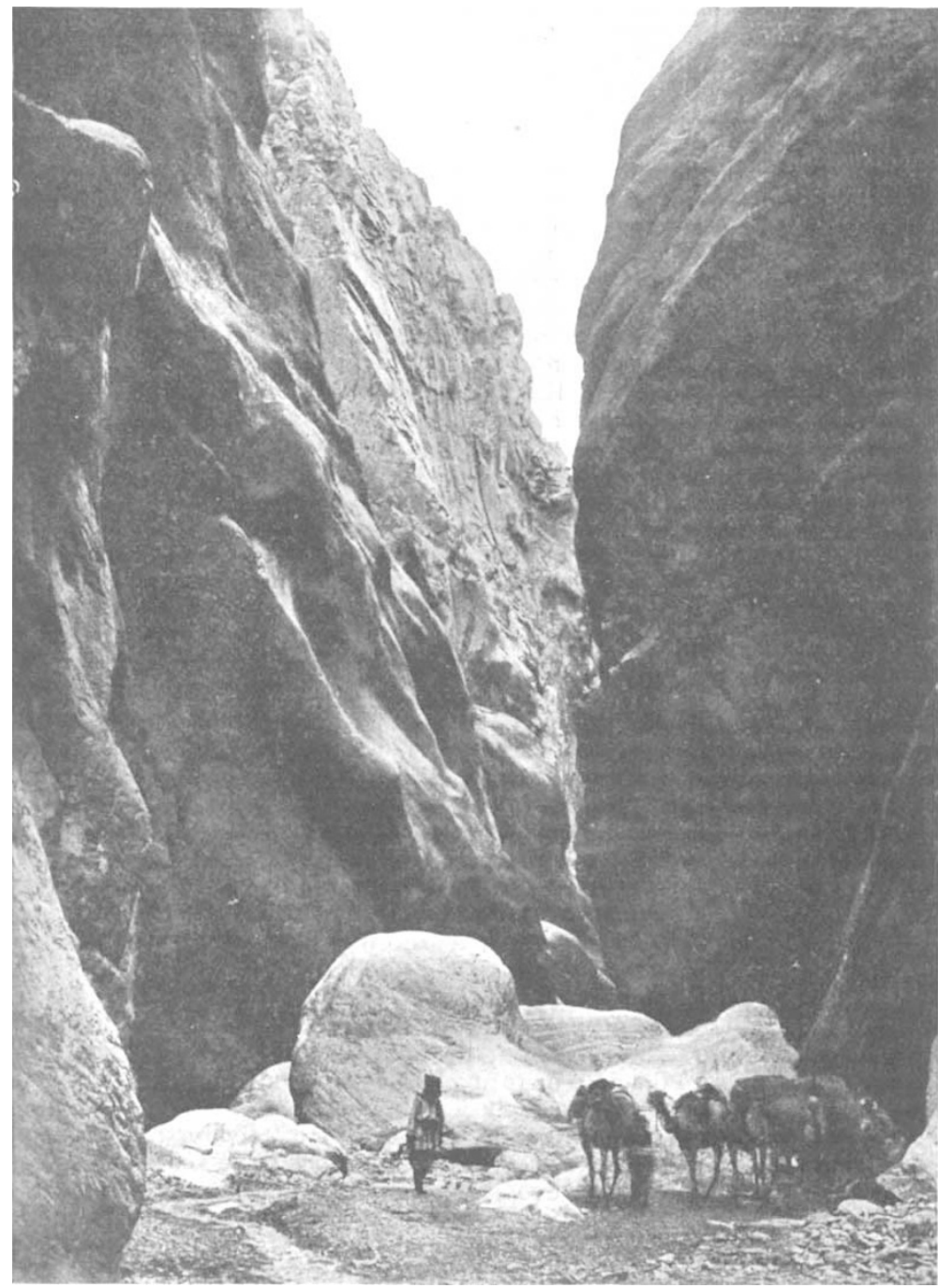

FIG. I. The road to the Takht-i-Suliman.

(From "The Indian Borderland, r880-1900.")

price which we have already paid for a false policy, not justified even by the seeming expediency of a critical time.

Of Makran, the Persian Gulf, and that place of contention, Koweit, Sir Thomas Holdich has very pleasant and instructive pages. Quite apart from the "professional" value of his judgments and his historical summaries, there is a graphic power in his descriptions which stamps the strange scenes deeply in the mind. Here, as in all his other wanderings, this genial, able Royal Engineer officer displays his love of nature's No. I 684 , voL. 65$]$ beauty. This makes his book, not only the most important publication of the time on the Indian frontier, but also the most agreeable to read. The illustrations are excellent, the map trustworthy and very useful.

\section{REPORT OF THE INDIAN PLAGUE COMMISSION.}

THIS report, consisting of five big volumes, is a record of the work of the Commission appointed by the Governor-General in Council, with the approval of the Secretary of State for India. The questions submitted to the Commission were four: (I) the origin of the different outbreaks of plague (in India); (2) the manner in which the disease is communicated; (3) the effects of curative serum; and (4) the effects of preventive inoculation.

The Commission, with Prof Fraser, F.R.S., as president, has collected in seventy meetings in different parts of India and in two additional meetings after their return in London, the stupendous amount of evidence embodied in three closely-printed large volumes in twenty-seven thousand questions and answers.

The summary of the conclusions arrived at by the Commission, after having examined a host of competent witnesses and after having carried out itself or directed a considerable amount of work concerning plague, is contained in vol. $v$. on more than 500 folio pages. From this it will be understood that the work of the Commission was carried out in a thorough manner. Add to this the fact that the Commission had prepared a large amount of work in the form of charts, tables, statistical summaries, \&c., and that after repeated and lengthy discussions amongst themselves the commissioners remained divided on several important points. We mention this to prepare the reader of the report for the surprise of not finding specific answers to the specific questions put to the Commission. This surprise is to a certain extent justified if we remember that various foreign commissions-Russian, Gernan, Austrian, Frenchwho have been sent out to India or Oporto respectively to study plague have in their reports given their Governments to understand that they have satisfactorily solved all and every problem concerning every point of the disease plague.

One has only to look through vol. v. of the report to feel convinced that the Commission has striven assiduously to find the specific answers; every page of this volume testifies to the desire to arrive at the correct conclusion; every assertion of fact brought before it was judicially and critically examined, compared and adjusted to its proper place and bearing. There can be, therefore, no question as to the thoroughness of the work itself. The cause of the deficiency of the answers must be sought elsewhere. In looking at the evidence of the witnesses and at the observations of 
the commissioners themselves, it will be seen that the answers were not found, partly because the data to hand were insufficient and partly because the problem of plague in India is of far greater complexity than we were led to expect, and because there were too many unexpected difficulties encountered by the Commission.

If one reads some of the self-sufficient conclusions of some modern writers on plague (including the above-mentioned reports of the foreign commissions), one is met by the apparent simplicity and seemingly satisfactory solution of the problem concerning the etiology, epidemiology, prophylaxis, treatment, \&c., of plague ; and yet here we have a commission, consisting of a number of the most able and highly qualified experts, examining, experimenting, criticising and discussing, and at the end of their labours they either fail to give a specific answer to the specific questions asked, or they are able to do so only in a fragmentary manner and under certain restrictions. The commissioners have not been able to trace when, whence and how plague came into Bombay; the com missioners are not able to state the manner in which plague was imported and how it spread in many localities in India; the commissioners are not able either to condemn or to recommend the use for therapeutic purposes of either Lustig's serum or Yersin's serum; and the commissioners express a not markedly decided, although on the whole a favourable, opinion about Haffkine's plague prophylactic. Although definite answers by the Commission to the four specific questions could not be given, many valuable opinions and facts concerning plague in India have been placed on record.

In the first place, the Commission: distinguished the mild (or ambulating) form of true bubonic plague from the severe form, the former as "pestis minor," the latter as "pestis major." This is a timely and important statement, because recently: some "plague experts" have tried to raise some febrile disease associated with glandular swelling, but which, according to their own showing, is not plague, that is to say, is not caused by the Bacillus pestis, to the position of "pestis minor," thereby creating and fostering misunderstanding.

Another important point is the confirmation by the Commission concerning the great importance of "locality" in the dissemination of plague (vol. v. p. IOI). "The universal experience of plague in India proves ... that houses into which the infection of plague has been imported, whether by man or by rats, are infective, this infectivity being so marked that many of the officers who have had most experience of the disease have come to the conclusion that the principal source of infection is ... to be found in the houses into which the infection of plague has been introduced."

Unfortunately, the Commission did not find sufficient data to explain the nature of this factor. Equally un satisfactory results attended the discussion as to the importance of rats in the dissemination of plague amongst human beings. But as regards the reality of the danger of clothes and personal effects of plague-infected persons in transmitting plague to new "localities," the Commission is very emphatic.

Not the least valuable part of the report consists in the indication of the nature of further work required for elucidating many of the points at present unsolved. Amongst these is the encouragement of further experimental work in the more accurate study of the blood of animals which furnish curative serum, and the importance of such work in obtaining a uniform strength and accurate standard of Haffkine's plague prophylactic.

No. I684, VOL. 65]

\section{A. W. BENNETT.}

A LFRED WILLIAM BENNETT, M.A., B.Sc., F.L.S., the well-known lecturer on botany at St. Thomas's Hospital, and for many years a prominent figure in botanical circles, died suddenly from heart disease on January 23. Born at Clapham in 1833, Mr. Bennett took the degree of B.A. (Lond.) in 1854 , and afterwards spent ten years in business as a publisher. During this period he employed photography in the illustration of books, and was one of the first, if not the first, to do so. Shortly after taking his M.A. degree he had the misfortune to fall from a horse, an accident that somewhat seriously affected his health throughout his subsequent life. When the publication of NATURE was commenced, Mr. Bennett was appointed as the first sub-editor, and he occupied that postion for several years. He received the appointment of lecturer on botany at St. Thomas's Hospital nearly thirty years ago. Botanical students will remember Mr. Bennett as the translator of the third edition of Sachs's classical "Lehrbuch der Botanik" and of Thomés Lehrbuch. His enthusiastic study of the flora of the Swiss Alps found expression in some important works for the use of students of Alpine botany. His translation of DallaTorre's "Tourist's Guide to the Flora of the Alps" was issued in 1886 , and previously he edited Seboth's "Alpine Plants Painted from Nature," a work in four volumes. His useful "Flora of the Alps," in two octavo volumes, accompanied by 120 coloured plates, appeared in 1897 . He devoted much attention to the Cryptogams, as witnessed by the excellent "Handbook of Cryptogamic Botany," a work executed in conjunction with Mr. George Murray and published in 1889. With regard to the systematic study of the Phanerogams, Mr. Bennett confined his labours chiefly to the Polygalaceæ, which he monographed for the "Flora of British India" and the "Flora Brasiliensis," dealing with the order also in some important papers contributed to the Journal of Botany. In the Royal Society's Catalogue of Scientific Papers he appears as the sole author of forty-six papers, many of which are based on his observations respecting the fertilisation of flowers. Elected a fellow of the Linnean Society in 1868 , he served for some years on the council of that society, and was one of the vice-presidents for I891-92. He was also a fellow of the : Royal Microscopical Society, of which he was a vice-president in I899-I900, and the editor of its Journal since 1897 .

S. A. S.

\section{NOTES}

AN influential committee has been formed with the object of establishing a memorial tower and meteorological station in honour of Dr. J. P. Joule, F.R.S., at Sale, Cheshire, where he lived from 1872 down to the time of his death in 1889 . Sir W. H. Bailey has offered to the Sale District Council an automatic recording meteorological and public clock made from designs which are the result of his investigations and inquiries with regard to similar instruments in this country and abroad. The instrument will be unique in its details; will indicate the time as a public clock on large dials, produce automatic graphic records of the various changes of temperature and the fluctuations of atmospheric pressure, and also changes of the wind and the rainfall of the district. In addition to this gift, which will cost about 250l., Mr. F. Armstrong has offered to the Council a set of instruments to equip a meteorological station, and the only condition attached to these gifts is that they shall be suitably housed. Designs for a building to be called "The Joule Memorial Tower," to contain the recording and other instruments, have been prepared, and the Council is willing to 